\title{
EVALUASI PENERAPAN ISO/IEC 17025:2017 TERHADAP KUALITAS PELAYANAN DAN KEPERCAYAAN PELANGGAN YANG BERDAMPAK PADA KINERJA MANAJERIAL LABORATORIUM QUALITY CONTROL PT XYZ
}

\author{
Yogie Pratama Sandi, Sahat Saragi, Maura Linda Sitanggang \\ Fakultas Farmasi, Universitas Pancasila, Jakarta, Indonesia \\ Email: yogiepsandi@gmail.com, sahatsaragi@yahoo.com, \\ mauralinda2012@yahoo.com
}

\begin{abstract}
Abstrak
Sebagai bagian untuk meningkatkan kinerja, kualitas pelayanan dan kepercayaan pelanggan, terutama perusahaan Toll Manufacturing, PT XYZ mendapatkan sertifikat ISO/IEC 17025: 2017 pada bulan maret 2020. Namun setelah penerapan standar tersebut cenderung terjadi penurunan jumlah perusahaan yang melakukan pengujian produk di Laboratorium PT XYZ. Tujuan penelitian ini adalah untuk menilai penerapan ISO/IEC 17025: 2017 dan pengaruhnya terhadap kualitas pelayanan dan kepercayaan pelanggan yang berdampak pada kinerja manajerial. Penelitian ini menggunakan metode penelitian kuanititatif dan desain deskriptif dengan pendekatan internal (balance scorecard) \& eksternal (Kuesioner). Sampel penelitian adalah data sekunder key performance indicator laboratorium dan pelanggan pengujian laboratorium dalam ruang lingkup ISO/IEC 17025: 2017 yang berjumlah 47. Hasil penelitian metode balanced scorecard diperoleh skor 3,5 (target $\geq 3$ ), artinya pencapaian target laboratorium memenuhi target yang telah ditetapkan dan responden dominan menjawab baik yang artinya laboratorium telah melaksanakan sistem manajemen mutu, dokumentasi yang terorganisir dan penerapan telah dilakukan pada rentang $61-80 \%$. Hasil penelitian pengaruh antar variabel menunjukkan Penerapan ISO/IEC 17025:2017 berpengaruh signifikan terhadap Kualitas Pelayanan (t: 2,535 \& p: 0,012), Kepercayaan Pelanggan (t: 2,332 \& p: 0,020) dan Kinerja Manajerial (t: 1,967 \& p: 0,0497). Selain itu hasil penerapan ISO/IEC 17025:2017 berpengaruh signifikan terhadap Kualitas Pelayanan (t: 2,202 \& p: 0,028) dan Kepercayaan Pelanggan (t: 2,052 \& p: 0,041) yang berdampak pada Kinerja Manajerial.
\end{abstract}

Kata Kunci: ISO/IEC 17025:2017; kinerja manajerial; kualitas pelayanan; kepercayaan pelanggan

\section{Abstract}

As part of improving performance, service quality and customer trust, especially Toll Manufacturing companies, PT XYZ has received ISO/IEC 17025: 2017 certificate in march 2020. However, after the implementation of these standard, there tends to be a decrease in the number of companies conducting product testing at Laboratory of PT XYZ. The purpose of this study is to assess the implementation

$\begin{array}{ll}\text { How to cite: } & \text { Sandi. Y.P., Sahat Saragi \& Maura Linda Sitanggang (2022) Evaluasi Penerapan ISO/IEC 17025:2017 } \\ & \text { Terhadap Kualitas Pelayanan dan Kepercayaan Pelanggan yang Berdampak Pada Kinerja Manajerial } \\ & \text { Laboratorium Quality Control PT XYZ. Syntax Literate: Jurnal Ilmiah Indonesia, 7(1). } \\ & \text { http://dx.doi.org/10.36418/ Syntax-Literate.v7i1.6027 } \\ \text { E-ISSN: } & \text { 2548-1398 } \\ \text { Published by: } & \text { Ridwan Institute }\end{array}$


Evaluasi Penerapan ISO/IEC 17025:2017 Terhadap Kualitas Pelayanan dan Kepercayaan Pelanggan yang Berdampak pada Kinerja Manajerial Laboratorium Quality Control PT XYZ

of ISO/IEC 17025: 2017 and its effect on service quality and customer trust which has an impact on managerial performance. This study uses quantitative research methods and descriptive design with an internal (balance scorecard) \& external (questionnaire) approach. The research sample is secondary data for laboratory key performance indicators and laboratory testing customers within the scope of ISO/IEC 17025: 2017 totaling 47. The results of the balanced scorecard method research obtained a score of 3,5 (target $\geq 3$ ), meaning that the achievement of laboratory targets meets the targets that have been set. determined and the dominant respondent answered well, which means the laboratory has implemented a quality management system, organized documentation and implementation has been carried out in the range of $61-80 \%$. The results of the research on the influence between variables show that the implementation of ISO/IEC 17025:2017 has a significant effect on Service Quality ( $t: 2,535 \&$ : $: 0.012)$, Customer trus ( $t$ : 2,332 \& p: 0.020) and Managerial Performance (t: 1,967 \& p: 0,00497). In addition, the results of the implementation of ISO/IEC 17025: 2017 have significant effect on Service Quality ( $t: 2,202 \&$ : 0,0028) and Customer Trust ( $t$ : 2,052 \& p: 0,0041) which have an impact on Managerial Performance..

Keywords: ISO 17025; service quality; managerial performance; customer trust

Received: 2021-12-20; Accepted: 2022-01-05; Published: 2022-01-15

\section{Pendahuluan}

Seri ISO/IEC 17025 merupakan sebuah standar yang diakui secara internasional dan pengakuan formal kompetensi laboratorium pengujian dan laboratorium kalibrasi melalui akreditasi, digunakan secara luas sebagai persyaratan diterimanya hasil pengujian dan hasil kalibrasi yang diperlukan oleh berbagai pihak di dunia (Murharyanti, 2012).

Berdasarkan data pada Komite Akreditasi Nasional (KAN) selama tahun 2021 terdapat 1531 laboratorium pengujian yang telah tersertifikasi ISO/IEC 17025. Hal ini menunjukkan sangat dibutuhkannya suatu sistem penjaminan kualitas untuk menjaga hasil pengujian. Namun, dari total tersebut hanya terdapat $5(0,33 \%)$ yang berasal dari laboratorium perusahaan farmasi (Komite akreditasi nasional, 2021).

Sebagai bagian untuk meningkatkan kinerja, daya saing, kualitas pelayanan dan kepercayaan pelanggan terutama pihak/perusahaan Toll Manufacturing, Laboratorium Quality Control PT XYZ mengajukan pendaftaran ISO/IEC 17025: 2017 untuk kategori pengujian sediaan injeksi dengan ruang lingkup pengujian osmolalitas, bahan partikulat/particulate matter, sterilitas dan bacterial endotoxin.

Laboratorium Quality Control PT XYZ telah mendapatkan sertifkat ISO/IEC 17025: 2017 pada bulan maret 2020 sebagai salah satu standar acuan sistem manajemen mutu. Penerapan ISO/IEC 17025:2017 yang baik dan konsisten diharapkan dapat dirasakan manfaat dan keunggulannya melalui peningkatan kualitas pelayanan dan peningkatan jumlah perusahaan yang mempercayakan pengujian produknya di laboratorium PT XYZ, sehingga hal ini akan berdampak pada pencapaian kinerja manajerial Laboratorium PT XYZ. 


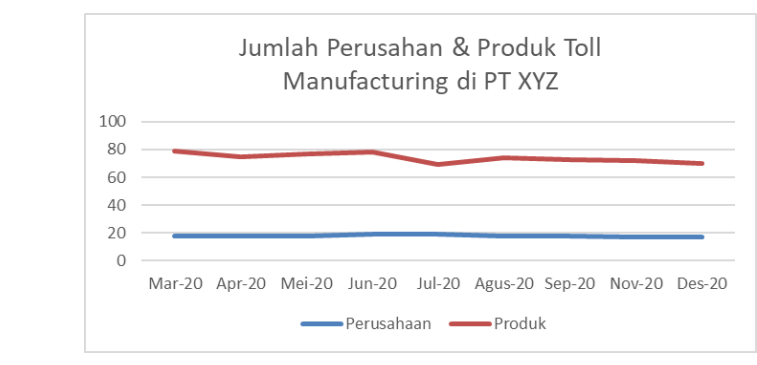

\section{Gambar I \\ Perusahaan dan Produk Tool Manufatcuring}

Berdasarkan data perusahaan yang mempercayakan pengujian produknya di Laboratorium PT XYZ sejak penerapan ISO/IEC 17025:2017 cenderung terjadi penurunan jumlah pelanggan, sehingga hal ini menunjukkan bahwa penerapan ISO/IEC 17025:2017 belum memberikan dampak yang berarti pada peningkatan jumlah perusahaan yang mempercayakan pengujian produknya di laboratorium PT XYZ.

Berdasarkan uraian diatas, peneliti ingin membahas lebih rinci masalah yang dialami Laboratorium PT XYZ melalui penelitian dengan judul "Evaluasi Penerapan ISO/IEC 17025:2017 (X) Terhadap Kualitas Pelayanan (Y1) Dan Kepercayaan Pelanggan (Y2) yang Berdampak Pada Kinerja Manajerial (Z) Laboratorium Quality Control PT XYZ".

\section{Metode Penelitian}

Penelitian ini adalah kuantitatif dan desain deskriptif dengan pendekatan balance scorecard \& penyebaran kuesioner (Sugiyono, 2017) dan (Cresswell, 2017). Data internal berupa data sekunder yang berasal dari laporan key performance indicator (KPI) Laboratorium Quality Control PT XYZ. Data eksternal berasal dari kuesioner kepada pelanggan yang melakukan pengujian di Laboratorium Quality Control PT XYZ dalam ruang lingkup ISO/IEC 17025:2017 menggunakan rumus slovin dengan tingkat kesalahan $5 \%$ terhadap total populasi

Analisis data pada penelitian ini dilakukan dengan metode Partial Least Square (PLS) (Irwan \& Adam, 2015). PLS adalah salah satu metode statistika SEM berbasis varian yang didesain untuk menyelesaikan regresi berganda ketika terjadi permasalahan spesifik pada data yakni ukuran sampel penelitian kecil, adanya data yang hilang dan multikolonieritas (Rahmawati, 2017). Tahap-tahap analisis data menggunakan model SEM SmartPLS ver.3 yaitu analisis outer model (pengukuran bagian luar), asumsi klasik, analisis inner model (pengukuran bagian dalam) dan pengujian hipotesa. 
Evaluasi Penerapan ISO/IEC 17025:2017 Terhadap Kualitas Pelayanan dan Kepercayaan Pelanggan yang Berdampak pada Kinerja Manajerial Laboratorium Quality Control PT XYZ

\section{Hasil dan Pembahasan}

Karakteristik data subjek penelitian dapat dilihat pada gambar $1-6$.

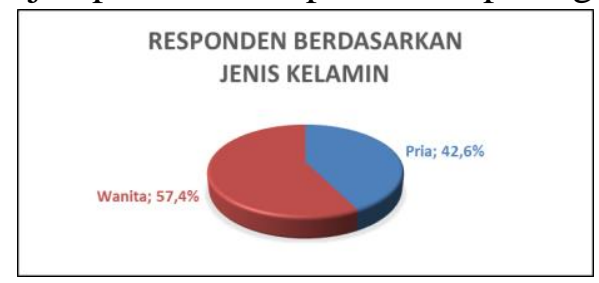

Gambar 2

Jenis Kelamin Responden

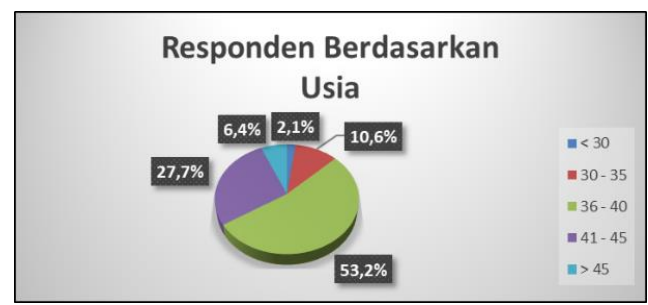

Gambar 3

Usia Responden

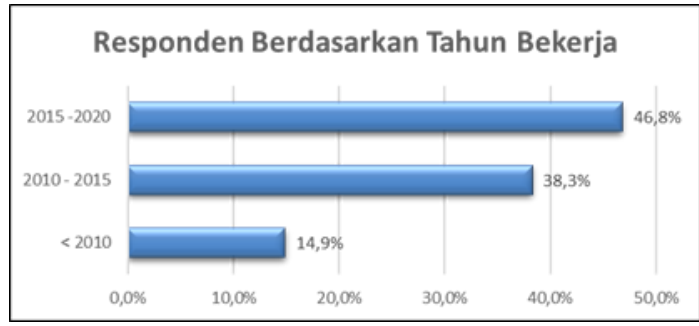

Gambar 4

Tahun Bekerja Responden

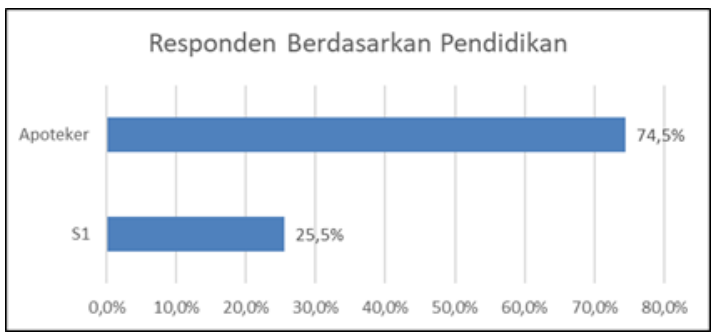

Gambar 5

Pendidikan Responden

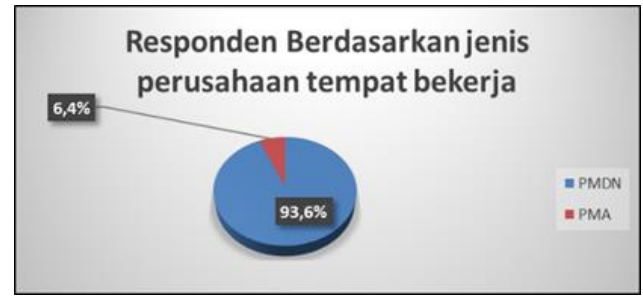

Gambar 6

Jenis Perusahaan Responden 


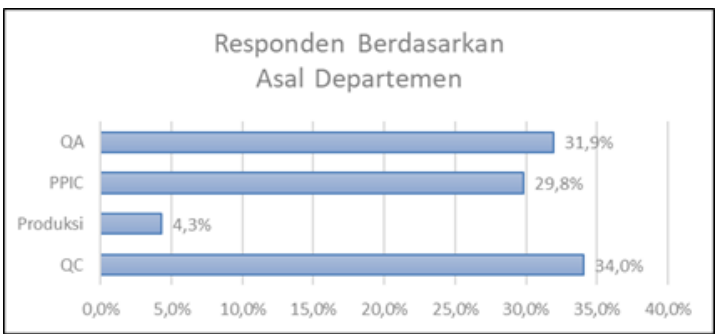

Gambar 7

Asal Departemen Responden

Berikut adalah persebaran jawaban responden berdasarkan variabel penelitian.

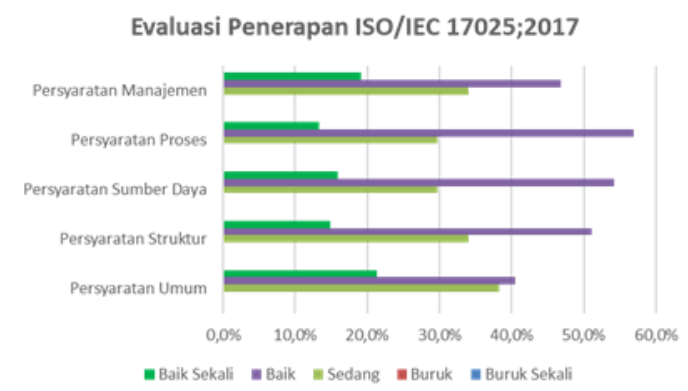

\section{Gambar 8}

Data survei ISO/IEC 17025

Hasil penelitian menunjukkan responden dominan menjawab kategori baik artinya laboratorium sudah melaksanakan sistem manajemen mutu, sudah adanya dokumentasi yang terorganisir dan penerapan sudah dilakukan pada rentang $61-80 \%$.

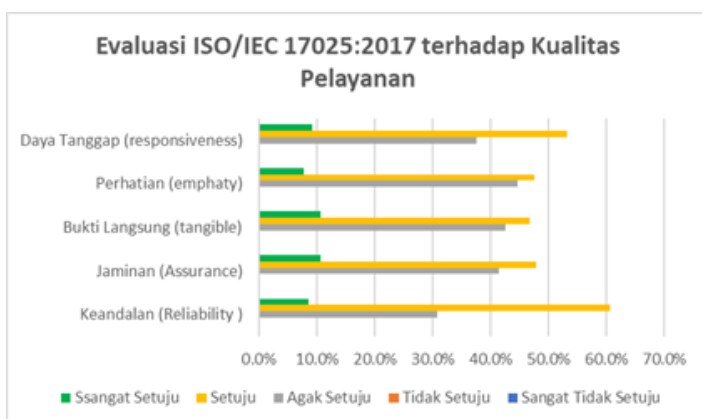

Gambar 9

Data survei Kualitas Pelayanan

Hasil penelitian menunjukkan responden dominan menjawab setuju pada setiap indikator, artinya pelayanan laboratorium sudah dilakukan secara optimal terhadap aktual dilapangan. 
Evaluasi Penerapan ISO/IEC 17025:2017 Terhadap Kualitas Pelayanan dan Kepercayaan Pelanggan yang Berdampak pada Kinerja Manajerial Laboratorium Quality Control PT XYZ

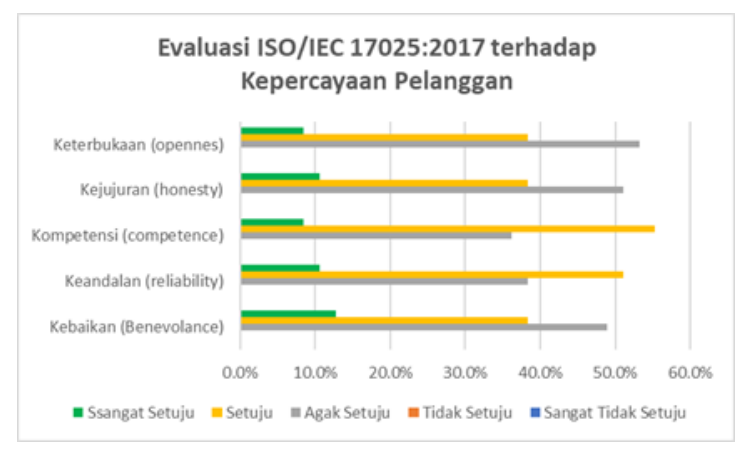

Gambar 10

Data survei Kepercayaan Pelanggan

Hasil penelitian menunjukkan responden dominan menjawab setuju pada setiap indikator, artinya responden meyakini pernyataan tentang laboratorium sudah dilakukan secara optimal terhadap aktual dilapangan.

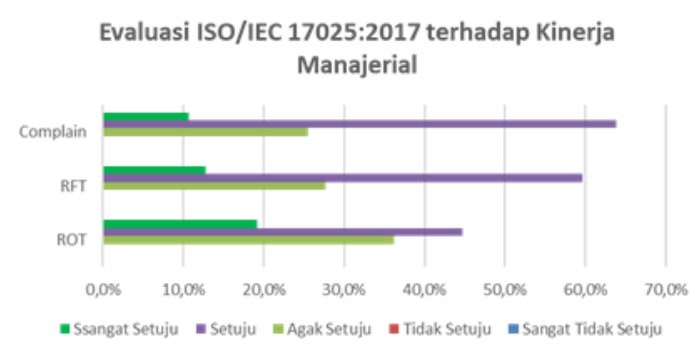

Gambar 11

Data survei kinerja manajerial

Hasil penelitian menunjukkan responden dominan menjawab setuju pada setiap indikator, artinya responden meyakini pernyataan tentang laboratorium sudah dilakukan secara optimal terhadap aktual dilapangan.

Tahapan analisis yang pertama dimulai dengan analisis outer model, dimana untuk memastikan bahwa pengukuran yang dipakai layak untuk dijadikan pengukuran. Pada pengujian outer model ada 3 parameter yang digunakan. Pertama adalah convergent validity untuk menggambarkan besarnya korelasi antar setiap item pengukuran (indikator) dengan konstruknya dengan mengukur nilai loading factor dimana nilai yang diharapkan $>0,7$. Kedua adalah reliability untuk menilai reliabilias suatu konstruk yang dapat diukur melalui nilai cronbach's alpha $>0,6$, nilai composite reliability $>0,7$, dan nilai average variance extracted (AVE) $>0,5$. Ketiga adalah discriminant validity menguji sampai seberapa jauh konstruk laten benar benar berbeda dengan konstruk lainnya (Zaiţ \& Bertea, 2011). Nilai discriminant validity yang tinggi memberikan indikasi bahwa suatu konstruk adalah unik dan mampu menjelaskan fenomena yang diukur. Cara pengukuran discriminant validity menggunakan yaitu membandingkan nilai Akar Kuadrat AVE (Fornell-larcker Criterion) (Furadantin, 2018), dimana nilai yang diharapkan lebih besar masing masing item lebih besar dari nilai item konstruk lainnya. 
Berikut adalah hasil pengujian outer Model pada penelitian ini:

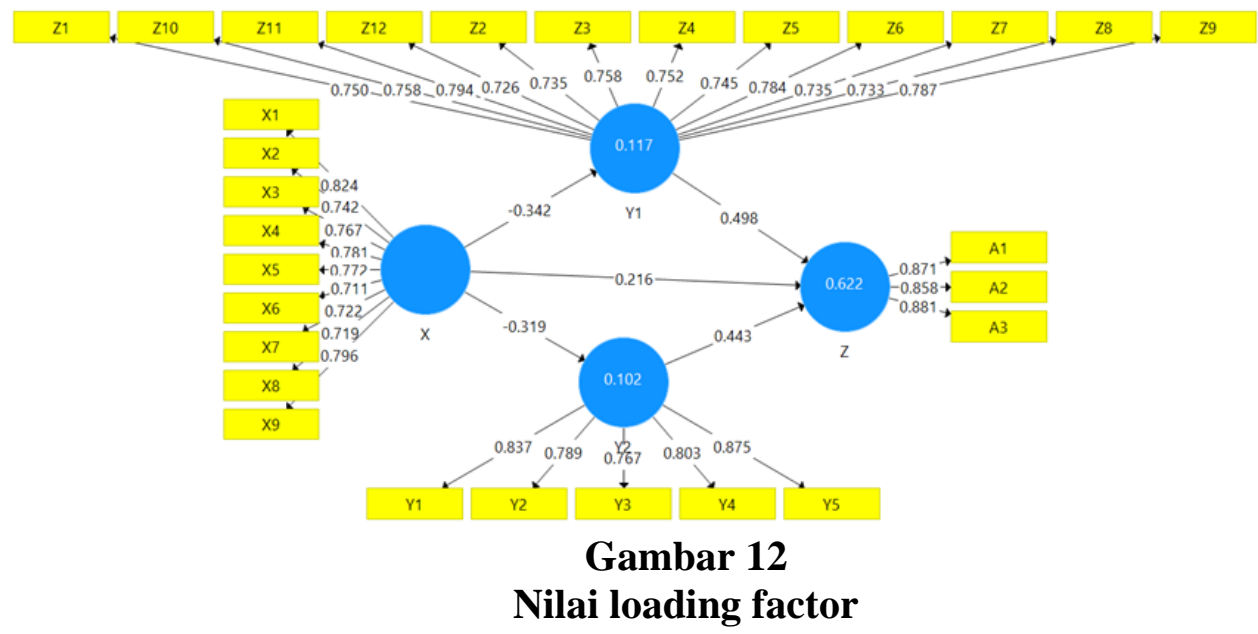

Berdasarkan hasil analisis dari tiap indikator telah memenuhi syarat, sehingga keempat variabel dinyatakan valid:

Tabel 1

Hasil uji reliability

\begin{tabular}{cccc}
\hline Var. & cronbach's alpha & composite reliability & Average variance extracted (AVE) \\
\hline $\mathrm{X}$ & 0,909 & 0,925 & 0,578 \\
\hline $\mathrm{Y} 1$ & 0,932 & 0,941 & 0,570 \\
\hline $\mathrm{Y} 2$ & 0,874 & 0,908 & 0,664 \\
\hline $\mathrm{Z}$ & 0,840 & 0,903 & 0,757 \\
\hline
\end{tabular}

Berdasarkan hasil analisis dari tiap variabel telah memenuhi syarat, sehingga keempat variabel dinyatakan reliabel.

\section{Tabel 2}

Nilai Akar Kuadrat AVE (Fornell-larcker Criterion)

\begin{tabular}{ccccc}
\hline Var. & $\mathrm{X}$ & $\mathrm{Y} 1$ & $\mathrm{Y} 2$ & $\mathrm{Z}$ \\
\hline $\mathrm{X}$ & 0,760 & & & \\
\hline $\mathrm{Y} 1$ & $-0,342$ & 0,755 & & \\
\hline $\mathrm{Y} 2$ & $-0,319$ & 0,603 & 0,815 & \\
\hline $\mathrm{Z}$ & $-0,096$ & 0,691 & 0,674 & 0,870 \\
\hline
\end{tabular}

Berdasarkan hasil analisis dari tiap variabel nilai akar dari AVE tiap konstruk lebih besar dari pada korelasinya dengan variabel lainnya, sehingga syarat validitas pada model ini telah terpenuhi.

Tahapan analisis kedua selanjutnya adalah uji asumsi klasik dengan melakukan pengujian multikolinearitas untuk melihat hubungan antar indikator, sehingga mengetahui apakah indikator formatif mengalami multikolinearitas dengan mengetahui nilai variance inflation afactor (VIF) (Akinwande, Dikko, \& Samson, 2015). Nilai VIF antara $<5$ - 10 dapat dikatakan bahwa indikator tersebut terjadi multikolinearitas 10. 
Evaluasi Penerapan ISO/IEC 17025:2017 Terhadap Kualitas Pelayanan dan Kepercayaan Pelanggan yang Berdampak pada Kinerja Manajerial Laboratorium Quality Control PT XYZ

Hasil nilai VIF pada setiap indikator adalah 1,438 - 4,362 yang menunjukkan bahwa tidak terjadi multikolinearitas antar indikator variabel.

Tahapan analisis yang ketiga adalah pengujian inner model yang dilakukan untuk memastikan bahwa model struktural yang dibangun kuat dan akurat, sehingga derajat kecocokan model tersebut diterima atau ditolak. Inner model dapat dievaluasi dengan beberapa tahapan, yang pertama adalah koefisian determinasi (R-Square dan Adjusted R-Square) merupakan cara untuk menilai seberapa besar konstruk endogen dapat dijelaskan oleh konstruk eksogen (Akossou \& Palm, 2013). Nilai koefisien determinasi diharapkan antara 0 dan 1 . Nilai koefisien determinasi kuat: > 75\%, sedang: $25-75 \%$, lemah: $<25 \% 11$.

Tabel 3

Nilai Koefisien determinasi

\begin{tabular}{lcc}
\hline Var. & $R$-Square & Adjusted $R$-Square \\
\hline Y1 & 0,117 & 0,097 \\
\hline Y2 & 0,102 & 0,082 \\
\hline $\mathrm{Z}$ & 0,622 & 0,595 \\
\hline
\end{tabular}

Berdasarkan hasil analisis koefisien determinasi tabel V.27 dapat dilihat bahwa nilai R Square pengaruh (X) terhadap (Y1) adalah sebesar 0,117 dengan nilai adjusted $\mathrm{r}$ square 0,097, maka dapat dijelaskan bahwa semua konstruk eksogen (X) mempengaruhi (Y1) sebesar 0,097 atau 9,7\%, dimana hasilnya < 0,25 (25\%), maka pengaruh semua konstruk eksogen (X) terhadap (Y) termasuk kategori lemah.

Nilai R Square pengaruh bersama - sama konstruk eksogen (X) dan (Y1) terhadap (Y2) adalah sebesar 0,103 dengan nilai adjusted $r$ square 0,082, maka dapat dijelaskan bahwa semua konstruk eksogen (X) dan (Y1) terhadap (Y2) sebesar 0,082 atau 8,2\%, dimana hasilnya $<0,25$ (25\%), maka pengaruh semua konstruk eksogen $(\mathrm{X})$ dan $(\mathrm{Y} 1)$ terhadap (Y2) termasuk kategori lemah.

Nilai R Square pengaruh bersama - sama konstruk eksogen (X), (Y1) dan (Y2) terhadap $(Z)$ adalah sebesar 0,622 dengan nilai adjusted $r$ square 0,595, maka dapat dijelaskan bahwa semua konstruk eksogen (X), (Y1) dan (Y2) terhadap (Z) sebesar 0,595 atau $59,5 \%$, dimana hasilnya $25-75 \%$, maka pengaruh semua konstruk eksogen $(\mathrm{X}),(\mathrm{Y} 1)$ dan (Y2) terhadap (Z) termasuk kategori sedang.

Kedua adalah uji kecocokan model dengan indikator penilaian nilai SRMR atau Standardized Root Mean Square <0,100. Hasil pengujian menunjukkan nilai SRMR 0,096 yang artinya penilaian model tersebut memenuhi kriteria kecocokan model, sehingga dapat disimpulkan bahwa model cocok dengan data.

Selanjutnya adalah pengujian hipotesis melalui analisis inferensia. Menguji hipotesis dapat dilihat dari nilai t-statistik dan nilai probabilitas. Untuk pengujian hipotesis menggunakan nilai statistik maka untuk alpha 5\% nilai t-statistik yang digunakan adalah 1,96. Sehingga kriteria penerimaan/penolakan Hipotesa adalah Ha diterima dan H0 di tolak ketika t-statistik >1,96. Untuk menolak/menerima hipotesis 
menggunakan probabilitas maka Ha di terima jika nilai $\mathrm{p}<0,05$. Berikut adalah hasil pengujian hipotesis.

\section{Tabel 4}

Pengujian Hipotesis

\begin{tabular}{clcccc}
\hline Hipotesis & \multicolumn{1}{c}{ Variabel } & Sampel Orginal & T-Statistic & P-value & Keterangan \\
\hline$H 2$ & $\mathrm{X}=>\mathrm{Y} 1$ & $-0,342$ & 2,535 & 0,012 & Signifikan \\
\hline H3 & $\mathrm{X}=>\mathrm{Y} 2$ & $-0,319$ & 2,332 & 0,020 & Signifikan \\
\hline H4 & $\mathrm{X}=>\mathrm{Y} 1=>\mathrm{Z}$ & $-0,170$ & 2,202 & 0,028 & Signifikan \\
\hline H5 & $\mathrm{X}=>\mathrm{Y} 2=>\mathrm{Z}$ & $-0,142$ & 2,052 & 0,041 & Signifikan \\
\hline H6 & $\mathrm{X}=>\mathrm{Z}$ & 0,216 & 1,967 & 0,0497 & Signifikan \\
\hline
\end{tabular}

Hasil analisis koefisien jalur menghasilkan t-statistic 2,535 (syarat > 1,96) dan pvalue 0,012 (syarat $<0,05$ ), dimana hasil tersebut memenuhi persyaratan, sehingga variabel Evaluasi ISO/IEC 17025:2017 terhadap Kualitas Pelayanan berpengaruh signifikan secara statistik. Dengan demikian dapat disimpulkan bahwa hipotesis 2 (H2) diterima, sedangkan hipotesis 0 ditolak. Hal ini menunjukkan berdasarkan analisis inferensia data primer penerapan ISO/IEC 17025: 2017 berpengaruh signifikan terhadap kualitas pelayanan.

Hasil analisis koefisien jalur menghasilkan t-statistic 2,332 (syarat > 1,96) dan pvalue 0,020 (syarat $<0,05$ ), dimana hasil tersebut memenuhi persyaratan, sehingga variabel Evaluasi ISO/IEC 17025:2017 terhadap Kepercayaan Pelanggan berpengaruh signifikan secara statistik. Dengan demikian dapat disimpulkan bahwa hipotesis 3 (H3) diterima, sedangkan hipotesis 0 ditolak. Hal ini menunjukkan berdasarkan analisis inferensia data primer penerapan ISO/IEC 17025: 2017 berpengaruh signifikan terhadap Kepercayaan pelanggan.

Hasil analisis melalui pengaruh tidak langsung (indirect effect) menghasilkan tstatistic 2,202 (syarat $>1,96$ ) dan p-value 0,028 (syarat $<0,05$ ), dimana hasil tersebut memenuhi persyaratan sehingga variabel Evaluasi ISO/IEC 17025:2017 terhadap Kualitas Pelayanan berdampak pada Kinerja Manajerial berpengaruh signifikan secara statistik. Dengan demikian dapat disimpulkan bahwa hipotesis 4 (H4) diterima, sedangkan hipotesis 0 ditolak. Hal ini menunjukkan berdasarkan analisis inferensia data primer penerapan ISO/IEC 17025: 2017 berpengaruh signifikan terhadap Kualitas Pelayanan yang berdampak pada Kinerja Manajerial.

Hasil analisis pengaruh tidak langsung (indirect effect) menghasilkan t-statistic 2,052 (syarat > 1,96) dan p-value 0,041 (syarat < 0,05), dimana hasil tersebut memenuhi persyaratan sehingga variabel Evaluasi ISO/IEC 17025:2017 terhadap Kepercayaan Pelanggan PT XYZ berdampak pada Kinerja Manajerial berpengaruh signifikan secara statistik. Dengan demikian dapat disimpulkan bahwa hipotesis 5 (H5) diterima, sedangkan hipotesis 0 ditolak. Hal ini menunjukkan berdasarkan analisis inferensia data primer penerapan ISO/IEC 17025: 2017 berpengaruh signifikan terhadap Kepercayaan Pelanggan yang berdampak pada Kinerja Manajerial. 
Evaluasi Penerapan ISO/IEC 17025:2017 Terhadap Kualitas Pelayanan dan Kepercayaan Pelanggan yang Berdampak pada Kinerja Manajerial Laboratorium Quality Control PT XYZ

Berdasarkan analisis koefisien jalur menghasilkan t-statistic 1,967 (syarat $>1,96$ ) dan p-value 0,0497 (syarat $<0,05$ ), dimana hasil tersebut memenuhi persyaratan, sehingga variabel Evaluasi ISO/IEC 17025:2017 terhadap Kinerja Manajerial berpengaruh positif dan signifikan secara statistik. Dengan demikian dapat disimpulkan bahwa hipotesis 6 (H6) diterima, sedangkan hipotesis 0 ditolak. Hal ini menunjukkan berdasarkan analisis inferensia data primer penerapan ISO/IEC 17025: 2017 berpengaruh signifikan terhadap Kinerja Manajerial.

Cara pengukuran dalam Balanced Scorecard adalah mengukur secara seimbang antara perspektif yang satu dengan perspektif yang lainnya dengan tolak ukur masing masing perspektif8 (Verlandes \& Hariati, 2019). Hasil dari ke 4 perpektif tersebut dijumlahkan kemudian dihitung nilai rata- ratanya.

\section{Tabel 5}

Hasil penelitian data sekunder

\begin{tabular}{|c|c|c|c|c|}
\hline Perspektif & Indikator & Bobot & Nilai & $\begin{array}{l}\text { Nilai } \\
\text { Akhir }\end{array}$ \\
\hline \multirow[t]{2}{*}{ Keuangan } & $\begin{array}{l}\text { Kesesuaian budget } \\
\text { pelaksanaan }\end{array}$ & $10 \%$ & 4 & 0,4 \\
\hline & Produktivitas Analis & $10 \%$ & 3 & 0,3 \\
\hline \multirow[t]{3}{*}{ Pelanggan } & Release On Time (ROT) & $15 \%$ & 4 & 0,6 \\
\hline & Right First Time (RFT) & $15 \%$ & 3 & 0,5 \\
\hline & Total Complain & $10 \%$ & 3 & 0,3 \\
\hline Bisnis Internal & Jumlah Inovasi (Kaizen) & $15 \%$ & 4 & 0,6 \\
\hline \multirow{3}{*}{$\begin{array}{c}\text { Pertumbuhan \& } \\
\text { Pembelajaran }\end{array}$} & Kualifikasi Personel & $10 \%$ & 4 & 0,4 \\
\hline & Jumlah Pelatihan karyawan & $15 \%$ & 3 & 0,5 \\
\hline & Total & $100 \%$ & 28 & 3,5 \\
\hline
\end{tabular}

Hasil penelitian menujukkan bahwa laboratorium mampu memanfaatkan budget yang telah dianggarkan. Pada ISO/IEC 17025: 2017 klausul 4 persyaratan struktural dimana disebutkan harus ada struktur organisasi dan tanggung jawab yang jelas serta perencanaan dan eksekusi yang baik dalam masalah keuangan, hal ini membantu untuk mengoptimalkan anggaran yang telah ditetapkan.

Selain itu peneliti juga menggunakan parameter produktivitas analis, sehingga dapat diketahui kapasitas maksimal pengujian yang bisa dianalisis sesuai dengan jumlah analis yang tersedia. Pada ISO/IEC 17025: 2017 klausul 5 persyaratan sumber daya dimana laboratorium harus menyediakan sumber daya yang memadai dalam hal ini termasuk analis untuk bisa memastikan operasional pelayanan laboratorium sesuai dan tepat waktu. Hasil penelitian menunjukkan bahwa produktivitas analis mencapai 21,6 bets/analis/bulan, yang menandakan bahwa laboratorium telah mampu mencapai target yang telah ditetapkan, yaitu $\geq 20$ bets/analis/bulan.

Pada perspektif pelanggan, peneliti mendapatkan data dari 3 parameter, yang pertama adalah Release on Time (ROT) yaitu kemampuan laboratorium untuk menyelesaikan analisis bahan baku / produk ruahan / produk jadi sesuai dengan komitmen atau target waktu yang telah ditetapkan sebelumnya. ROT merupakan salah 
satu parameter yang sangat penting dalam menentukan kinerja laboratorium, karena berhubungan langsung dengan janji/kesepakatan labroatorium kepada pelanggan, dimana hal ini jika tercapai akan membantu meningkatkan kepercayaan pelanggan. Berdasarkan data rata-rata pencapaian target ROT tahunan yakni 97,27\%, dengan kategori nilai 4 dimana target internal ROT laboratorium adalah $\geq 96,00 \%$, maka bisa disimpulkan bahwa pencapaian target ROT memenuhi target yang telah ditetapkan.

Kedua adalah Right First Time (RFT) yaitu kemampuan laboratorium untuk menghasilkan data analisis hanya dari satu kali pengujian (tidak ada pengulangan karena human error) (Park, 2008). Berdasarkan data rata-rata pencapaian target RFT tahunan yakni 2,01\%, dengan kategori nilai 3 dimana target internal RFT laboratorium adalah $\leq$ $2,5 \%$, maka bisa disimpulkan bahwa pencapaian target RFT memenuhi target yang telah ditetapkan.

Ketiga adalah Total complain yang dihitung berdasarkan jumlah atau frekuensi complain yang dikirimkan oleh pelanggan kepada laboratorium, baik itu terkait analisis maupun laporan hasil analisis. Berdasarkan data total complain yakni 0,83\%, dengan kategori nilai 3 dimana target internal total complain laboratorium selama rentang waktu 1 tahun (12 bulan) adalah $\leq 1,0 \%$, maka bisa disimpulkan bahwa pencapaian target RFT memenuhi target yang telah ditetapkan.

Pada perspektif inovasi peneliti menggunakan satu parameter yaitu inovasi yang dilakukan oleh karyawan (dari level manajer sampai dengan analis) yang telah diimplementasikan selama rentang waktu maret 2020 sampai dengan februari 2021 dalam ruang lingkup kategori ISO/IEC 17025:2017. Berdasarkan data total inovasi yakni berjumlah 5, dengan kategori nilai 3 dimana target internal inovasi laboratorium selama rentang waktu 1 tahun (12 bulan) adalah $\leq 5$, maka bisa disimpulkan bahwa pencapaian target RFT memenuhi target yang telah ditetapkan.

Pada perspektif pertumbuhan dan pembelajaran peneliti menggunakan 2 parameter yaitu keberhasilan pelaksanaan kualifikasi (termasuk re-kualifikasi) dan pelatihan rutin internal laboratorium yang telah diimplementasikan selama rentang waktu maret 2020 sampai dengan februari 2021 dalam ruang lingkup kategori ISO/IEC 17025:2017. Berdasarkan data realisasi pelaksanaan kualifikasi yakni berjumlah 4 analis, dimana seluruh pelaksanaan sesuai dengan jadwal yang telah ditetapkan, maka diberi kategori nilai 4 dimana target internal pelaksanaan kualifikasi (termasuk rekualifikasi) laboratorium sesuai dengan jadwal, maka bisa disimpulkan bahwa pencapaian pelaksanaan kualifikasi (termasuk re-kualifikasi) memenuhi target yang telah ditetapkan. Berdasarkan data realisasi pelaksanaan Latihan/training yakni berjumlah 4 materi, dimana untuk materi pengujian bahan partikulat menggunakan LOPC dan pengujian menggunakan osmometer memiliki durasi pelaksanaan masing masing 60 menit dan materi pengujian sterilitas \& bacterial endotoxin memiliki durasi pelaksanaan masing - masing 30 menit. Secara keseluruhan apabila dijumlah seluruh pelaksanaan training memiliki durasi 180 menit, maka diberi kategori nilai 3 dimana target internal pelaksanaan training adalah 180 - 240 menit/personel/tahun, maka bisa 
Evaluasi Penerapan ISO/IEC 17025:2017 Terhadap Kualitas Pelayanan dan Kepercayaan Pelanggan yang Berdampak pada Kinerja Manajerial Laboratorium Quality Control PT XYZ

disimpulkan bahwa pencapaian pelaksanaan training memenuhi target yang telah ditetapkan.

Berdasarkan data balance scorecard kinerja laboratorium yakni 3,5, dengan kategori baik dimana target internal kinerja laboratorium selama rentang waktu 1 tahun (12 bulan) adalah $\geq 3$, maka bisa disimpulkan bahwa pencapaian target laboratorium memenuhi target yang telah ditetapkan.

\section{Kesimpulan}

Evaluasi Penerapan ISO/IEC 17025:2017di Laboratorium Quality Control PT XYZ mendapatkan kategori baik dan memenuhi target internal laboratorium, dimana laboratorium sudah melaksanakan sistem manajemen mutu, sudah adanya dokumentasi yang terorganisir dan penerapan sudah dilakukan pada rentang $61-80 \%$. Penerapan ISO/IEC 17025:2017 berpengaruh signifikan terhadap Kualitas Pelayanan Laboratorium Quality Control PT XYZ. Penerapan ISO/IEC 17025:2017 berpengaruh signifikan terhadap kepercayaan pelanggan Laboratorium Quality Control PT XYZ. Penerapan ISO/IEC 17025: 2017 berpengaruh signifikan terhadap Kualitas Pelayanan yang berdampak pada Kinerja Manajerial Laboratorium Quality Control PT XYZ. Penerapan ISO/IEC 17025: 2017 berpengaruh signifikan terhadap Kepercayaan Pelanggan yang berdampak pada Kinerja Manajerial Laboratorium Quality Control PT XYZ. Evaluasi Penerapan ISO/IEC 17025: 2017 berpengaruh signifikan terhadap Kinerja Manajerial Laboratorium Quality Control PT XYZ. 


\section{BIBLIOGRAFI}

Akinwande, Michael Olusegun, Dikko, Hussaini Garba, \& Samson, Agboola. (2015). Variance inflation factor: as a condition for the inclusion of suppressor variable (s) in regression analysis. Open Journal of Statistics, 5(07), 754. Google Scholar

Akossou, A. Y. J., \& Palm, Rodolphe. (2013). Impact of data structure on the estimators R-square and adjusted R-square in linear regression. Int. J. Math. Comput, 20(3), 84-93. Google Scholar

Cresswell, J. W. (2017). Research Design: Pendekatan Kualitatif, Kuantitatif, dan Mixed (Edisi Ketiga). Yogyakarta: Pustaka Belajar. Google Scholar

Furadantin, R. (2018). Analisis Data Menggunakan Aplikasi SmartPLS V. 3.2. 72018. Jurnal Manajemen, 1(1), 1-18. Google Scholar

Irwan, Irwan, \& Adam, Khaeryna. (2015). Metode partial least square (PLS) dan terapannya (Studi kasus: analisis kepuasan pelanggan terhadap layanan PDAM unit camming kab. Bone). Teknosains: Media Informasi Sains Dan Teknologi, 9(1), 5368. Google Scholar

Komite akreditasi nasional. (2021). Direktori Klien Laboratorium penguji tersertifikasi ISO/IEC 17025:2017.

Murharyanti, Rika. (2012). Evaluasi Penerapan Sistem Manajemen Mutu Iso 9001 Dan Pengaruhnya Terhadap Kinerja Manajerial Dan Konsistensi Mutu Produk Vaksin Di PT. Bio Farma (Persero). Universitas Gadjah Mada. Google Scholar

Park, Jim. (2008). Right-first-time (RFT) production: the control strategy. Colourage, 55(2), 34-37. Google Scholar

Rahmawati, Mari. (2017). Pengaruh Penggunaan Cyberpreneurship Sebagai Media Pemasaran dalam Dunia Bisnis. Jurnal Sistem Informasi, 6(1), 26-33. Google Scholar

Sugiyono. (2017). Metode Penelitian Kuantitatif, Kualitatif, dan R\&D. Bandung: Alfabeta.

Verlandes, Yuliasnita Verlandes, \& Hariati, Suspa. (2019). Implementasi Pengukuran Kinerja Pada Pemerintah Kabupaten Jombang dengan Menggunakan Metode Balance Scorecard. PRIVE: Jurnal Riset Akuntansi Dan Keuangan, 2(2), 112-128. Google Scholar

Zaiţ, Adriana, \& Bertea, PSPE. (2011). Methods for testing discriminant validity. Management \& Marketing Journal, 9(2), 217-224. Google Scholar 
Evaluasi Penerapan ISO/IEC 17025:2017 Terhadap Kualitas Pelayanan dan Kepercayaan Pelanggan yang Berdampak pada Kinerja Manajerial Laboratorium Quality Control PT XYZ

\section{Copyright holder:}

Yogie Pratama Sandi (2022)

First publication right:

Syntax Literate: Jurnal Ilmiah Indonesia

This article is licensed under:

(c) (i) (O) 